\title{
AC 2010-2395: COLLECTIVE SYSTEM DESIGN IN SYSTEMS ENGINEERING EDUCATION
}

\section{David Cochran, Massachusetts Institute of Technology}

Dr. David S. Cochran Managing Partner System Design, LLC.

Dr. Cochran is one of the world's authorities on production and enterprise systems engineering and supply chain techniques and technologies.

As an MIT Mechanical Engineering faculty professor (1995-2003), he established the Production System Design (PSD) Laboratory at MIT (1995). He is a two-time recipient of the prestigious Shingo Prize (1989 and 2002) for manufacturing excellence for his work in the design of effective "lean" systems. He also received the Dudley Prize for best paper from the International Journal of Production Research in 2000. A special issue of the Journal of Manufacturing Systems (v. 20, No. 6 2001/2002) highlights his work with Automotive and Aerospace industries. Dr. Cochran teaches as adjunct faculty at Meijo University in Nagoya, Japan -- School of Business management. He is a member of the Meijo Process Management Institute, an international collaborative consultancy and is an adjunct member of the Systems Engineering faculty at Southern Methodist University, Dallas, Texas.

Through his company, System Design, LLC, which he founded in 2003, Dr. Cochran has consulted with both small and large companies who want to improve their cost and quality. These include: Revenge Advanced Composites (a specialty boat manufacturer), Lockheed Martin (F-22, JSF, Space Systems, Missiles and Fire Control: PAC-3), NASA, Visteon Automotive, Robert Bosch Corp., Ford Motor Company, Dell Computer, SAP, HP and Kinetic Systems. 


\title{
Collective System Design in Systems Engineering Education
}

\author{
David S. Cochran \\ Yong Suk Kim
}

\begin{abstract}
Collective System Design combines the academic disciplines of social science, organizational learning, Industrial and Systems Engineering to support the design and implementation of sustainable systems. Collective System Design is an integrative course for the Systems Engineering Curriculum at Southern Methodist University. Students apply the Collective System Design methodology to design a sustainable lean manufacturing system as part of an inclass physical system design and simulation workshop. The students then apply Collective System Design within their own work environments. The result of the new system design is to identify both hard savings and soft savings that show up on the bottom line for their company. Collective System Design uses a logic framework that defines the Functional Requirements that a system must effectively meet to satisfy internal and external customer needs.

The first challenge is listening to and understanding customer needs. Functional Requirement(s) formally state the need(s) of the customer as the condition(s) of system success. In the spirit of the Toyota Production System DNA ${ }^{1}$, the students learn to define Physical Solutions to achieve the Functional Requirements of success for the system in which they work. Each Physical Solution is stressed and treated as a hypothesis to achieving each system Functional Requirement. $^{2}$

The students learn that to reduce cost the system design itself must first be put in place. The underlying hypothesis is that sustainable and profitable enterprises must meet customer needs. They also learn the importance of performing Kaizen and Continuous Improvement actions once the new system design is put in place to further reduce cost by eliminating the waste that exists in the newly launched standard work practices.

Collective System Design acknowledges four elements: tone, logic, enterprise structure, and standard work action. The approach proposes that these elements are required for human beings to design successful and sustainable systems and that these elements must be designed and implemented as a whole. The rationale is that these elements form the architecture of the DNA of successful and sustainable human enterprises/systems.
\end{abstract}

\footnotetext{
${ }^{1}$ Bowen and Spear, The DNA of the Toyota Production System, HBR, 1999; http://hbswk.hbs.edu/item/0869.html

${ }^{2}$ Alan Ward, Lean Product and Process Development; http://www.amazon.com/Lean-Product-ProcessDevelopment-Allen/dp/1934109134)
} 


\section{The Factory as the Laboratory}

Manufacturing is diverse and involves attempting to achieve multiple objectives simultaneously within systems that require human decision making. Therefore, it is difficult to convey the complexity that exists within manufacturing systems in the classroom alone. For that reason, Professor Cochran has established partnerships with local, Boston manufacturing companies. The goal of that partnership is a win-win for both the students and the company sponsors. The company sponsor is able to reap the benefit of the students' work in manufacturing problem solving. The students gain the benefit of learning how to solve a real manufacturing problem. Therefore, they must learn how to define and solve a problem in a meaningful way to achieve the desired result in a limited period of time. The students work with different people within the company from the vice president level to the operators' level. They gain insights that many people who work within the company do not have because they are able to see the factory as a system, in an unbiased way. The students gain knowledge from many different areas of the company including manufacturing engineering, product design, finance, material supply, sales and marketing, and even the company union representatives. Because of their exposure, the students learn that solving manufacturing systems problems requires not only technical knowledge but also inter-personal knowledge and skills.

\section{Class Organization}

In the very early part of the course, the Vice Presidents of sponsoring companies visit MIT and give presentations regarding their company and provide an overview of the proposed projects to establish the importance of the proposed projects. It is very important to cooperate with sponsoring companies in this course. After having background information on the sponsoring companies and the proposed projects from the presentation session, the students then visit the sponsoring company and see the actual production. Then, the students select a project. The projects range from the formation of manufacturing cells, machine and fixture design for manufacturing flexibility, setup time reduction, or other specific problems. Throughout the term, students apply material from the classroom to create effective solutions for the company to consider. To make this happen, a point of contact is assigned to each project so that students can have access to the necessary information and can organize factory visits, independently. It is a key to the success of this course that the sponsoring companies open their doors to students and share the information to solve real manufacturing problems. Professor Cochran calls this relationship with industry and academia, "the Factory as the Laboratory."

\section{Using Collective System Design to Define the Manufacturing System Design Problem}

Collective System Design (CSD) uses the Axiomatic Design methodology to express the thinking layer of a system design. A system design consists of four layers, according to CSD: the tone, the thinking, the business structure, and standard work/action. Any system design is hypothesized to emanate from the tone that is present in a system. Tone can be positive or negative. The tone creates an inherent bias in a designer's viewpoint. Since the design of manufacturing systems includes people and their inherent thinking; bias is part any system design endeavor. CSD acknowledges that the first step of a large system design that includes people in that system is to understand tone and to express tone in a positive manner. Collective System Design starts with the tone and moves to thinking, then structure and then codifies and lastly defines the work procedure to implement a system design in the form of standard work. 
The standard work is continuously improved and must define the content, sequence and timing of all work that is performed by all people in the system that is designed.

\section{Collective System Design:}

to diagnose an existing system and to design a new system after conscious choice.

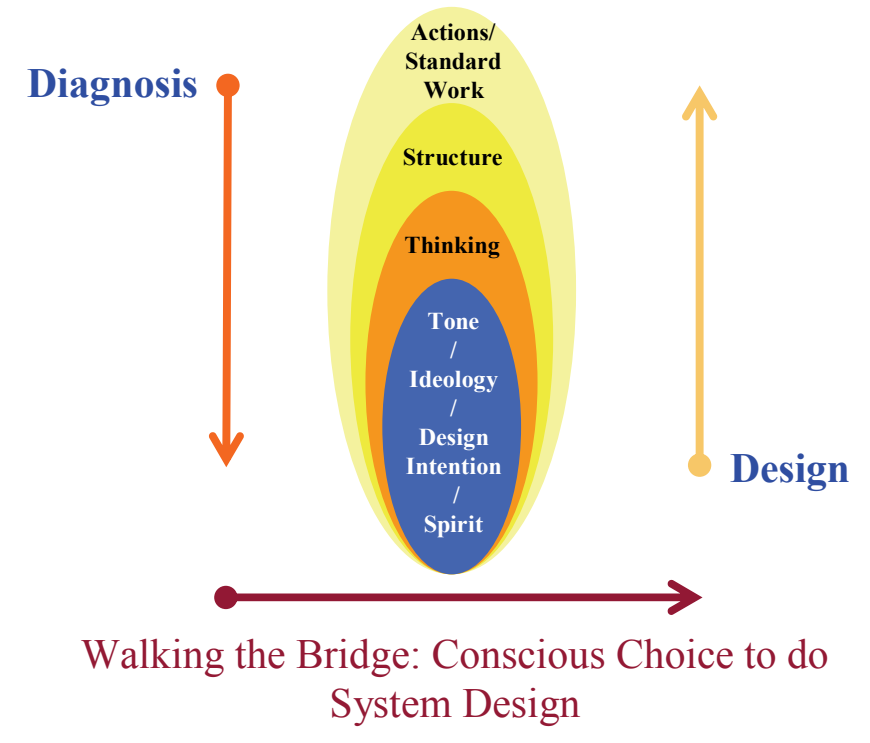

Figure 1. Sustainable Systems Effectively Meet Customer Needs and Require a Common Mental Model of the Design

The common mental model of a system design starts with the tone and design intention of the system. Axiomatic Design is used to codify the thinking that results from the tone / design intention. Enterprise structure results from the thinking. Structure includes company organization, performance measures, information technology infrastructure, personnel policy management and financial accounting practices. 


\section{Collective System Design: The Thinking Laver Defines FRs and PSs}

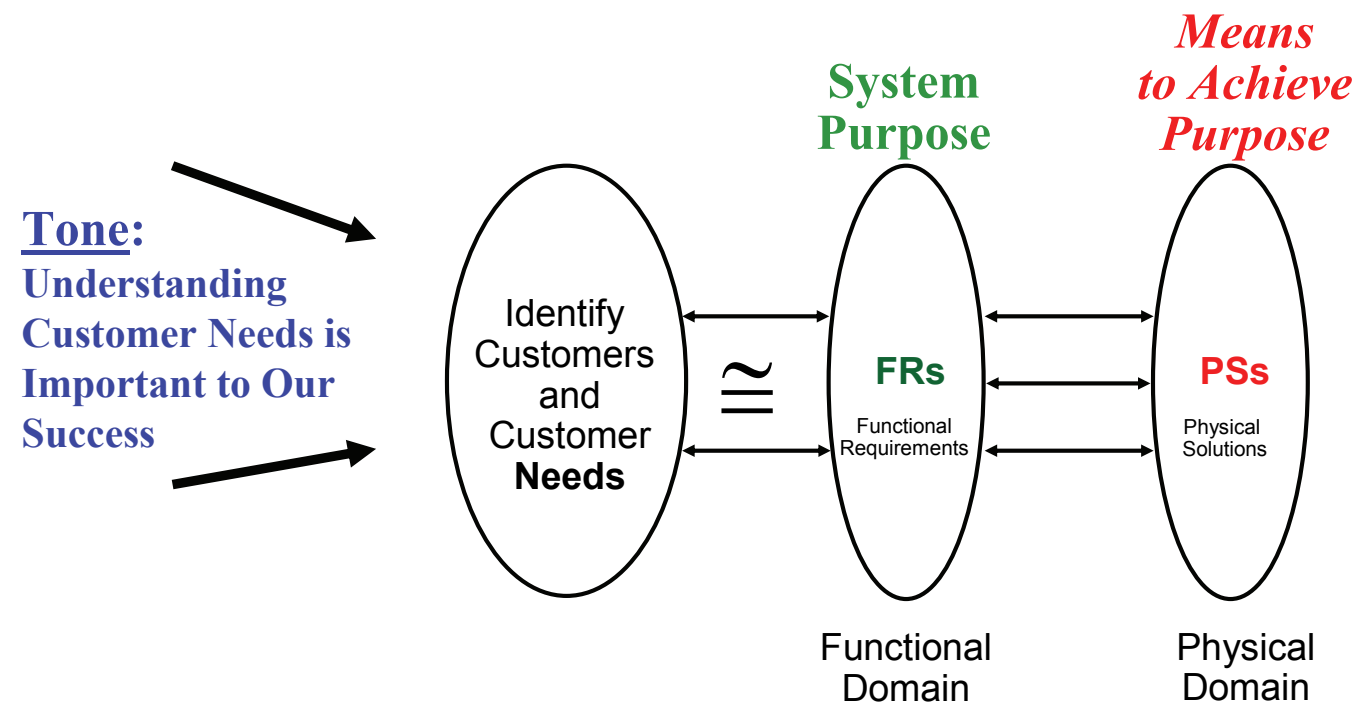

Functional Requirements $=$ FRs

Physical Solutions $=$ PSS $=$ Design

Parameters $=D P S$

Figure 2. The Thinking Layer Translates Customer Needs to System Purpose and Means (the Means to Achieve System Purpose is Treated as a Design Hypothesis)

The first problem that students usually meet is that project objectives are loosely stated by the sponsoring company. Therefore, the students must determine the true objectives and the corresponding solutions for their project. For this purpose, the students use Axiomatic Design as the methodology to convey the manufacturing system design problem ${ }^{2,8,9}$. The students state system purpose by using natural-language statements called FRs - Functional Requirements. FRs define what a system must do to meet customer needs. Next, the students state the physical means to achieve system purpose. The Physical Solution, or PS, is the prerogative of the system design and is sometimes called a Design Parameter or DP. The critical idea is to separate the means PS/DP (technical solution) from the FR, which states what a system must do to be successful. The INCOSE definition of requirements gathering does not distinguish purpose from means. System design mapping or zig-zagging creates a decomposition hierarchy of purpose and means as illustrated in Figure 3. A Design Matrix (DM) is used to express the relationship of the DPs to the FRs; the desired goal is to choose a DP to effect only the intended FR. This selection process minimizes the interaction of a DP on other FRs. The best design at any level of decomposition results in diagonal matrix or an upper or lower triangular relationship matrix of $\mathrm{FR}=[\mathrm{DM}]^{*} \mathrm{DP}$. An upper or lower triangular DM is path dependent and requires a specific sequence of DPs for implementation. A diagonal matrix requires no pre-defined sequence of DP implementation. Most large systems are path dependent. A system design is said to be coupled when iteration of the DPs is required to achieve the FRs. Engineering optimization and trade-off analysis deals with coupled systems. Surprisingly, many large enterprise systems can be converted from coupled to path-dependent systems. For example, building a house can be done 
as a path-dependent system when the plumbing is installed at the proper time in the build sequence of the house. However, coupling occurs if the plumbing is changed after the walls are installed and the slab foundation is poured. Manufacturing systems also have path dependency. For example, on-time delivery may be path dependent on process quality, depending on the system design.

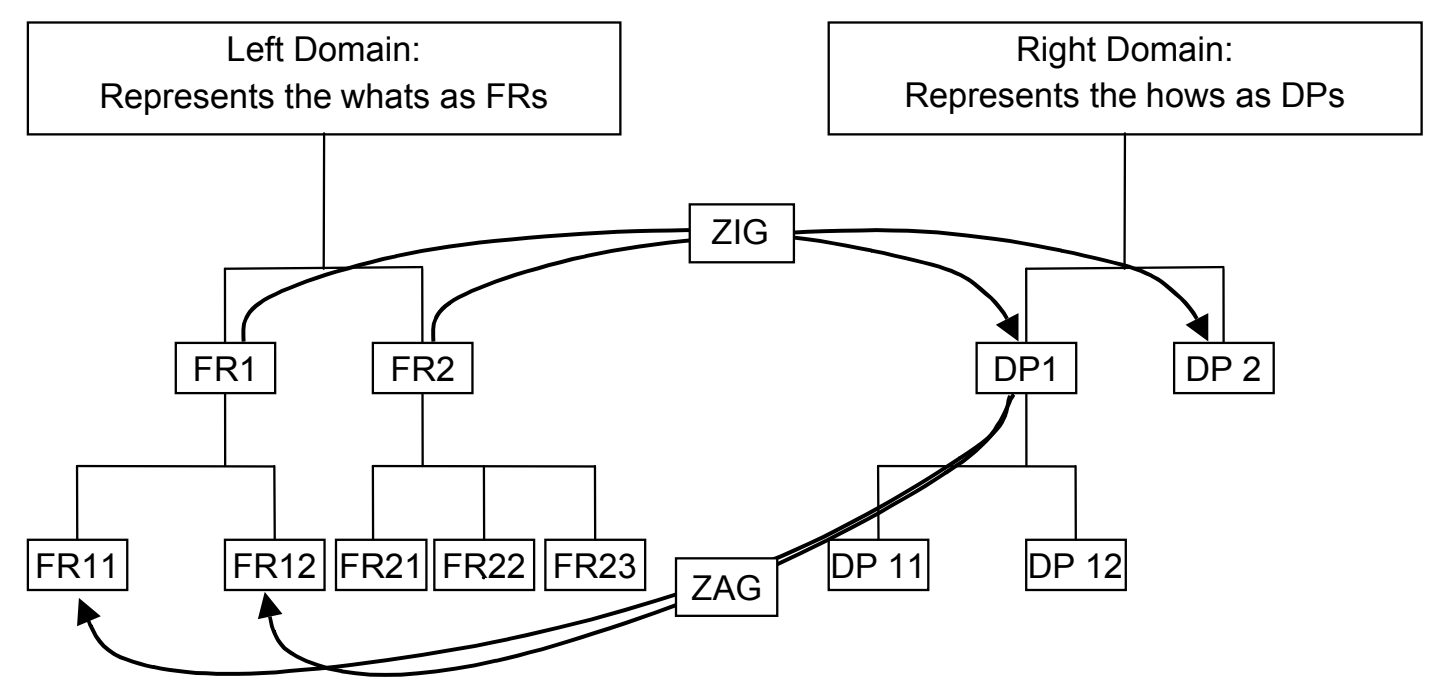

\begin{tabular}{|ll|}
\hline \multicolumn{2}{|c|}{ ZIG } \\
\hline 1. & Conceptualize \\
2. & Mapping FR $=[\mathrm{DM}]^{\star} \mathrm{DP}$ \\
3. & Prove the Independence Axiom \\
\hline
\end{tabular}

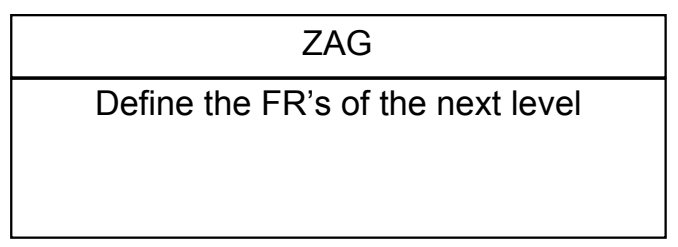

Figure 3. The Zigzagging Process of Axiomatic Design

When goal statements from companies are compared to re-defined goal statements from students that are developed based on Collective System Design Principles, it is evident that students and the sponsoring company benefit from using the design methodology. As shown in Table 1 and Table 2, initial project statements from companies are so nebulous that it is difficult to see the core of problems and imagine the possible solutions. 
Table 1. The Goal Statements from Companies

\begin{tabular}{|c|l|}
\hline $\begin{array}{c}\text { Project Titles } \\
\begin{array}{c}\text { Tuthill: } \\
\text { Mesign of Linked Cell } \\
\text { Manufacturing System }\end{array}\end{array}$ & $\begin{array}{l}\text { Goal Statements from Companies } \\
\text { "Determine the internal and external customers of the plant, and } \\
\text { calculate a takt time. Design a linked cell manufacturing system } \\
\text { for the plant, with a clear and logical flow of both the products } \\
\text { and the information. In other words, how can the information } \\
\text { generated in assembly be cascaded back to the rest of the plant, } \\
\text { allowing the takt time to be met?" }\end{array}$ \\
\hline $\begin{array}{c}\text { United Electric: } \\
\text { Wire Processing }\end{array}$ & $\begin{array}{l}\text { "95\% of the probes' built-in sensors require lead-wire } \\
\text { assemblies, the process of measuring, cutting, jacket stripping } \\
\text { and lead stripping is the single longest step in the production of } \\
\text { probes. The current process is tedious and difficult to adapt to } \\
\text { mixed-lot processing. We would benefit from any technologies } \\
\text { or systems that could reduce the process time." }\end{array}$ \\
\begin{tabular}{c|l} 
United Electric: \\
Miniaturize 105/120 \\
T/B Assembly Fixture
\end{tabular} & $\begin{array}{l}\text { "In our Toyota Production (TPS) pilot cell, there is a fixture } \\
\text { used to aid in the assembly of terminal blocks. This project } \\
\text { would examine the current method and make improvements to } \\
\text { poka-yoke (mistake-proof) and miniaturize the process." }\end{array}$ \\
\hline
\end{tabular}

Table 2. Problems with Sponsor Company Statements

\begin{tabular}{|c|c|c|c|}
\hline Sponsor Company & $\begin{array}{c}\text { Unclear } \\
\text { Objective }\end{array}$ & $\begin{array}{c}\text { Unclear } \\
\text { Solution }\end{array}$ & Comments \\
\hline $\begin{array}{c}\text { Tuthill. } \\
\text { Design of Linked Cell } \\
\text { Manufacturing System }\end{array}$ & $\mathrm{X}$ & $\mathrm{X}$ & $\begin{array}{c}\text { System } \\
\text { Design }\end{array}$ \\
\hline $\begin{array}{c}\text { United Electric } \\
\text { Wire Processing }\end{array}$ & $\mathrm{X}$ & $\mathrm{X}$ & $\begin{array}{c}\text { Sub-system } \\
\text { Design }\end{array}$ \\
\hline $\begin{array}{c}\text { United Electric } \\
\text { Miniaturize 105/120 T/B } \\
\text { Assembly Fixture }\end{array}$ & $\mathrm{X}$ & $\mathrm{X}$ & $\begin{array}{c}\text { Machine / } \\
\text { Fixture } \\
\text { Design }\end{array}$ \\
\hline
\end{tabular}

However, when those statements from companies are turned into FRs and DPs, the objectives of projects and corresponding solutions become very clear. Next, three examples will show how the design approach helps students to structure their thinking processes. Examples are presented 
according to their level within the system: system design level, machine design level, and fixture design level.

\section{Example 1. (System Design Level): Design of Linked Cell Manufacturing System (Tuthill) ${ }^{1}$}

The Kinney Vacuum division of Tuthill Corporation manufactures various types of vacuum pumps such as rotary piston, liquid ring, and dry screw pumps. 340 standard pumps and customized pumps are produced in the unionized plant in Massachusetts.

In this project, students sought a way to streamline the system for production signaling (pull) and coordination of material flow with the key upstream processes and the stockroom kitting function. The scope of this project is limited to the production of standard rotary vacuum pumps.

After getting knowledge on the current production system, the students thought of the design decomposition starting from the functional requirement of "produce \& supply only parts that are needed.' Following the zigzagging process and checking the design matrices, they designed a new system followed by a discussion on feasible implementation of design parameters (DPs). The design decomposition of this project is as shown in Figure 4. The design matrices are shown in Figure 5.

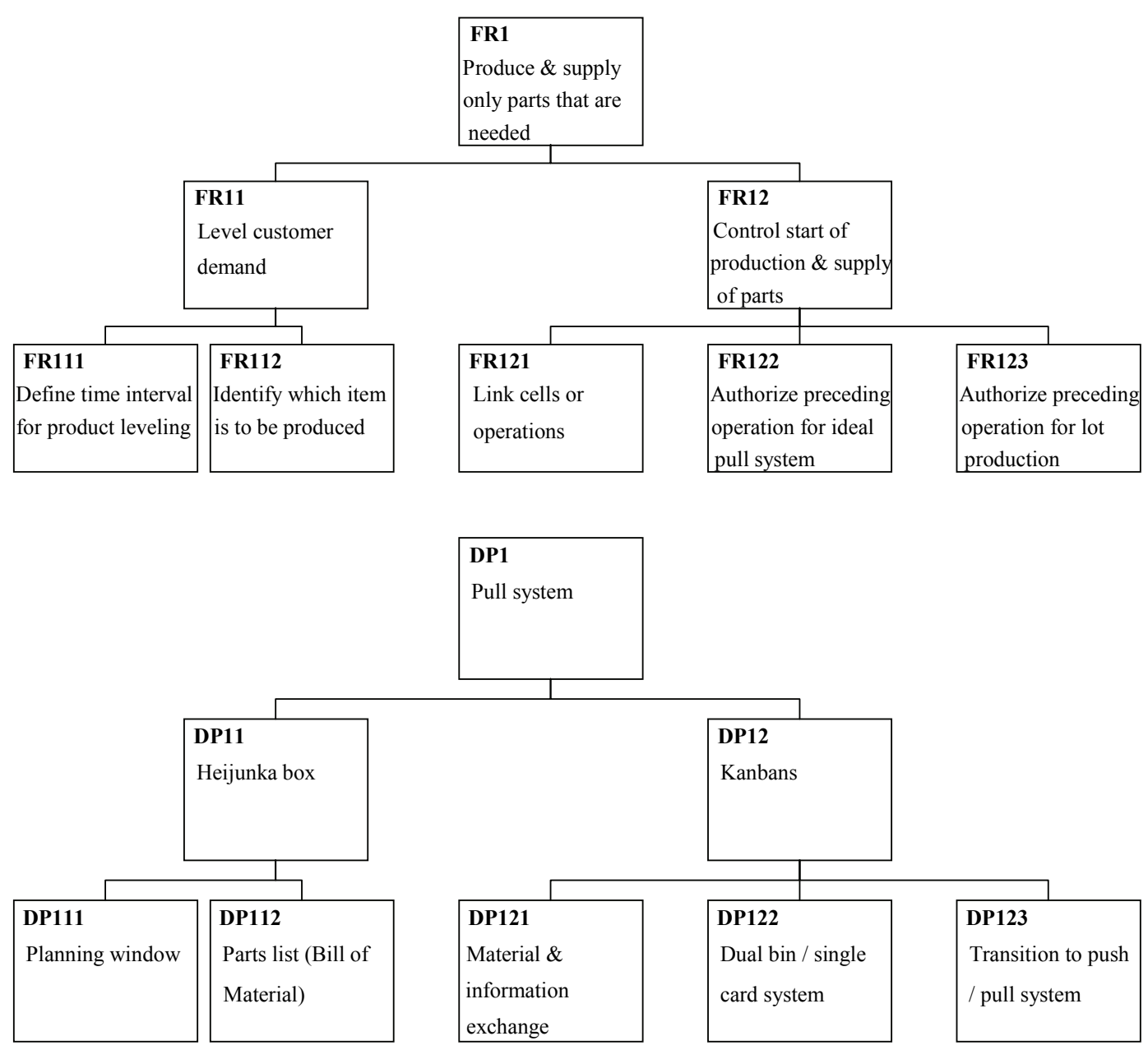

Figure 4. Decomposition of the 'Design of Linked-Cell Manufacturing System' Project 


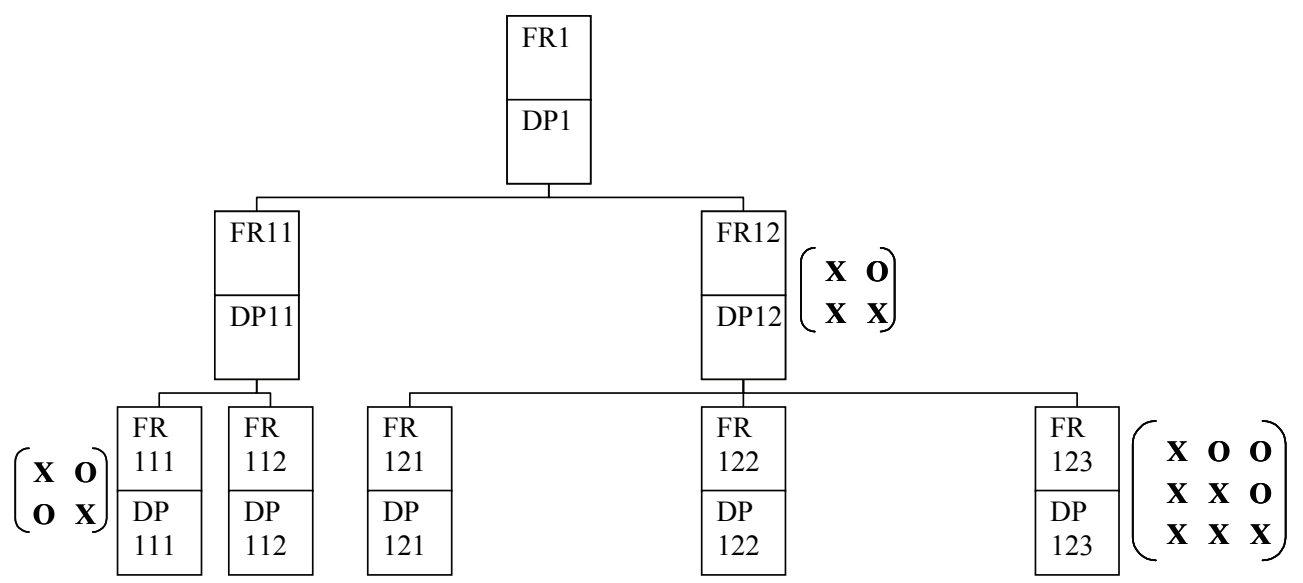

\section{Figure 5. Design Matrices [DM] of 'Design of Linked-Cell Manufacturing System' Project}

The Design Matrix [DM] at level 2 of the decomposition hierarchy illustrates that DP11 must be put in place prior to DP12 (recall the form of the equation is $\mathrm{FR}=[\mathrm{DM}]^{*} \mathrm{DP}$. Interestingly, DP11 is the Heijunka box and DP12 is the implementation of kanban. In most implementations of "lean," kanban is implemented prior to the Heijunka Box. A Heijunka Box is used to level the content, sequence and timing of demand on the standard work in process inventory between cells. When the demand exceeds the Standard Work In Process (SWIP) for any given pull signal, the kanaban system reaches an out-of-stock condition. Sometimes Heijunka Box is not implemented at all and leads to a collapse of the kanban system. For this reason, a Heijunka Box acts as the drumbeat for the overall system, just as the pacemaker (the person in the front of boat who exclaims "pull" to the crew) does in regatta racing.

The final picture of the new system is proposed and shown by incorporating all DPs into the new system. The proposed material and information flow of the new system is shown in Figure 6.

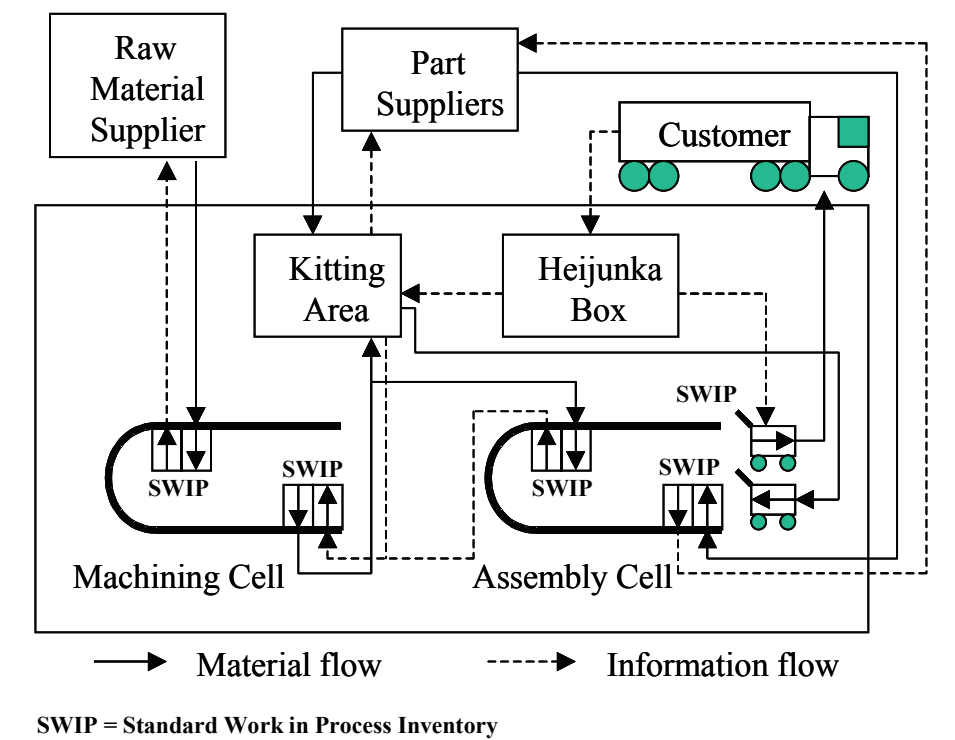

Figure 6. Material and Information Flow of the New Linked-Cell System 


\section{Example 2. (Sub-System Level): Wire Processing (United Electric) ${ }^{7}$}

United Electric (UE) is a privately held company located in Watertown, Massachusetts that produces temperature and pressure gauges. UE employs about 200 people and the annual revenue is about 400 million in U.S. dollars.

In this project, students' objective was to transform the current batch process of wire processing into a single-piece flow process. Batch production in wire process is required due to the long changeover time and lack of man/machine separation in the first three processes, so that the current wire processing does not meet 1 minute takt time. To solve this problem, students set the first FR as 'meet customer takt time' and decomposed it into lower levels. The design decomposition of this project is shown in Figure 7.

As seen in the design decomposition of Figure 7, the nebulous statement of the goal in Table 1 is translated into the clear goal to meet the customer takt time. Furthermore, more specified functional requirements to achieve this goal could be thought by decomposing it according to the Axiomatic Design methodology. Since the design level is subsystem (cell) level that is lower than system design, more physical design parameters are shown up such as DP113 on/off switch, DP132 Funnel guides, etc. Based on this design decomposition, students could design machines in the cell to satisfy all end level functional requirements (leaf FRs) by end level design parameters (leaf DPs) and thus actually implement them. The design matrices of this design decomposition are shown in Figure 8. 

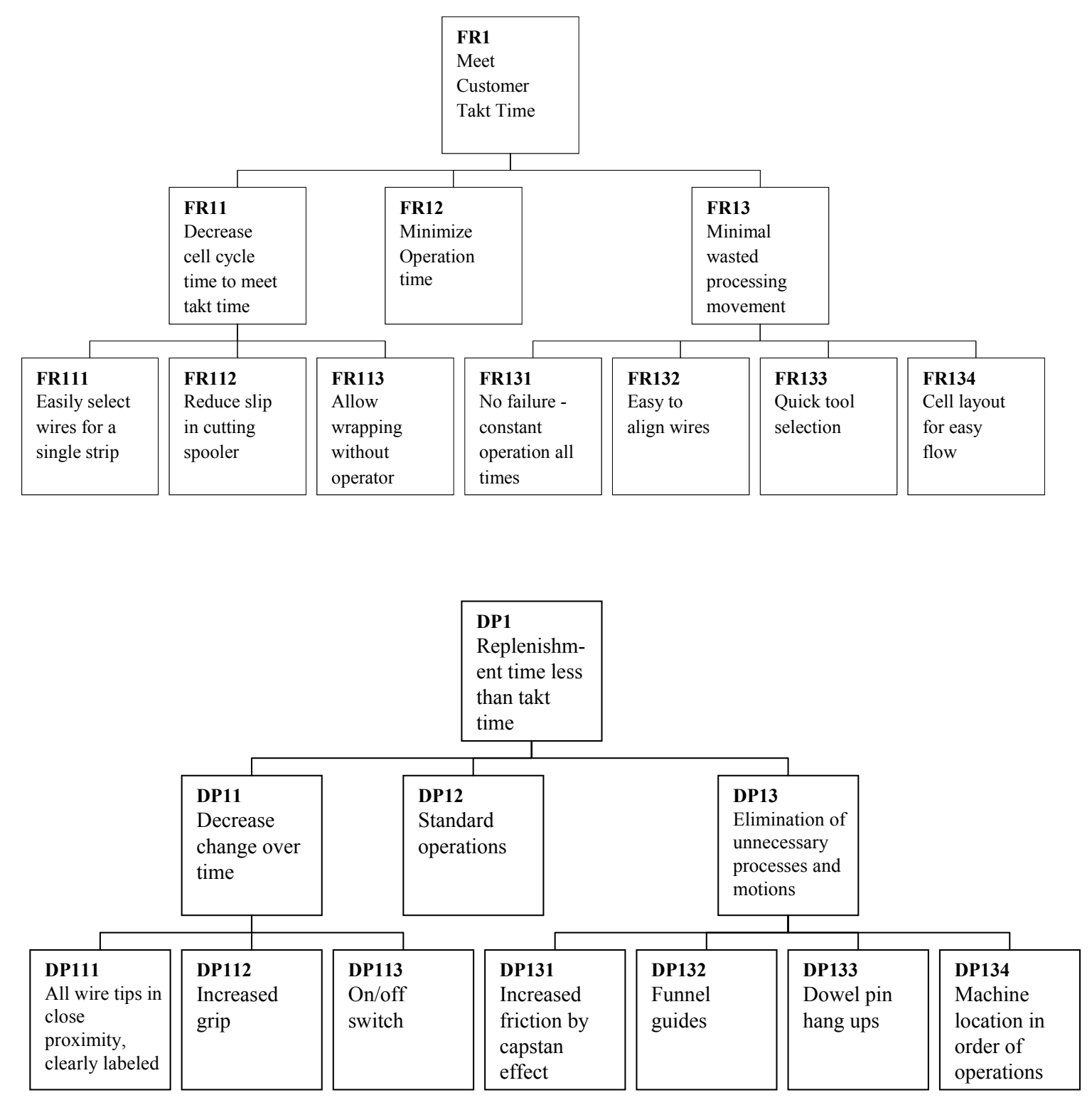

Figure 7. Design Decomposition of the 'Wire Processing' Project

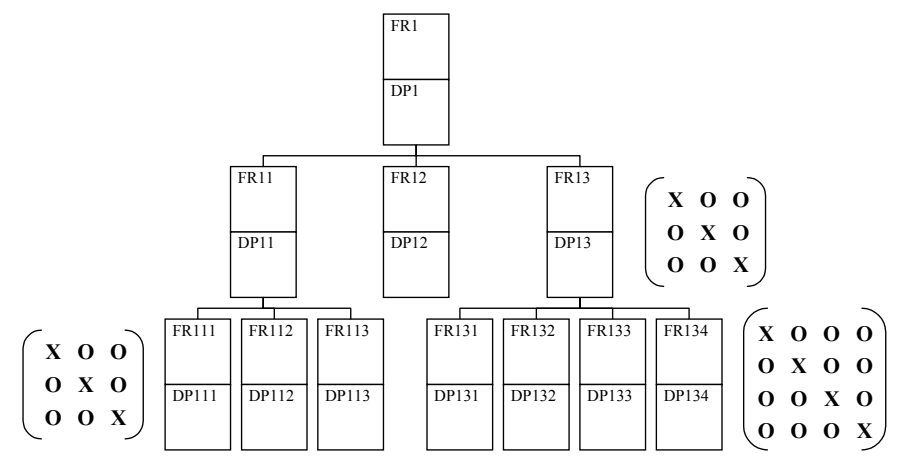

Figure 8. The Design Matrices of the 'Wire Processing' Project 


\section{Conclusions}

The new teaching method developed by Prof. Cochran provides a unique opportunity for students to learn about production system design. The combination of classroom instruction and real factory experience is a good way to help students to understand both the theoretical fundamentals and actual implication of production system design. The use of Collective System Design in the classroom strengthens the decision-making process in system design and provides rigorous, explainable results to the industrial participants. Students are able to think of real-life manufacturing design problems and strive to tackle them. Most impressively, the students are able to see the implementation of their solutions.

This teaching method benefits two parties: the students and the community. The students who have taken this course will enter the engineering community with a different attitude toward the real factory floor due to their experience in this course. In fact, it is this experience that has led some participating companies to hire several students to continue working for them. The community equally benefits from this new teaching method. Participating companies think of their problems in a more logical way in corporation with the students. In many cases, the companies are provided solutions to their problems. In addition, the companies learn how to tackle the manufacturing system problems and how to solve those problems with Collective System Design.

Collective System Design provides clear advantages in defining problems and finding corresponding solutions in a myriad of design processes. Students learned that it is important to always consider the objectives (functional requirements) while seeking answers (design parameters) to problems and to select DPs to ensure functional independence. To portray breadth and depth, this paper has illustrated the application of Collective System Design to the system, sub-system, and machine/fixture levels of production systems.

\section{References}

[1] Albers, T., Clampitt, C., Goss, B., and Lulgjuraj, M., "Kinney Vacuum Plant - Linked Cell Manufacturing System," 2.812 Class report, MIT, 1999.

[2] Cochran, D. S., "The Production System Design and Deployment Framework," Proceedings of Society of Automotive Engineers; International Automotive Manufacturing, SAE-IAM 99, May 1113, 1999.

[3] Cochran, D.S., "The Need for a Systems Approach to Enhance and Sustain Lean," Lean Accounting, Chapter 11, ed. J. Stenzel., Wiley and Sons, 2007.

[4] Geraci, J., Hansen, S., and Owens, M., "120/105 Cell - Terminal Block Fixture Redesign,” 2.812 Class report, MIT, 1998.

[5] Gupta, M. S., (editor) Teaching Engineering: A Beginner's Guide, New York: IEEE Press, 1987.

[6] Kosaraju, S. N. and Zue, T. S., "The Factory as a Classroom: Effective Methods of Teaching Lean Manufacturing," 2.82 Class report, MIT, 1998.

[7] Martinez, J., Reyes, A., and Roushdy, O., "Wire Processing Area Project", 2.812 Class report, MIT, 1998.

[8] Suh, N. P., Principles of Design, New York: Oxford University Press, 1990.

[9] Suh, N. P., Cochran, D. S., and Lima, P. C., "Manufacturing System Design," Annals of $48^{\text {th }}$ General Assembly of CIRP, Vol. 47, No. 2, 1998, pp. 627-639. 